\title{
Connectivity Beyond the Urban Community in Central Italy
}

\section{Corinna Riva}

Institute of Archaeology, University College London, London WC1H OPY, UK

Email: c.riva@ucl.ac.uk

\begin{abstract}
Two significant recent developments concerning the archaeology of Iron Age Central Italy call for a fresh analysis of settlement dynamics in the region and their relations vis-à-vis one another. The first development is the reconsideration of ancient urban centres as single entities and the need, which has mostly been advocated for the classical and later historical Mediterranean, to examine the systems or networks within which these centres functioned. The second development is the increasing amount of fieldwork-based research in those regions that have been situated at the margins of scholarly interest, partly because of their delay in urban development. New data from such research increasingly allow us to see the networks or systems that linked these regions to better-known ones on the Tyrrhenian coast. Such developments enable us to reassess the importance traditionally given to the core urban area of central Italy, and to offer a more balanced framework for understanding the exchange dynamics amongst Iron Age Central Italian communities. This chapter intends to do precisely that, and in so doing, its aim is twofold: first, to decentralise central Italy in line with studies on other Mediterranean regions that have similarly dispelled distinctions between core urban areas and non-urban peripheries; secondly, to shift attention away from evolutionary and other categories towards a perspective that stresses connectivity and patterns of human mobility.
\end{abstract}

\section{Introduction}

Urbanization has dominated the scholarship of Iron Age (IA) Central Italy over the last thirty years or so (cf. most recently, Sgubini Moretti 2005) to the extent that many studies of first millennium BC Italy have been defined as 'urbanocentric' (Bradley 2000: 30). Yet, two significant developments are providing the impetus for a reassessment of settlement dynamics in the region. The first development, which is visible in much recent scholarship on and across the ancient Mediterranean, invites us to reconsider the nature of ancient urban centres as single entities, and, in some cases, minimizes the importance of these with evident consequences; a key cause-and-effect of this re-evaluation, as we shall see, is the eagerly advocated need for the Classical and later historical Mediterranean to examine the systems and networks within which towns functioned and the indissoluble link between the former and the latter. The second development is the increasing amount of fieldwork-based research in those Italian regions that have been situated at the margins of scholarly interest, partly because of their delay in processes of urban formation. New data from such research increasingly allow us to identify and study the networks and systems that linked these regions to the better-known mid-Tyrrhenian region.

With all this in mind, it is now possible to reassess the significance usually given to the core urban area of Central Italy, the mid-Tyrrhenian coastal region, and to offer what can be 
seen as a more balanced framework for understanding the nature of, and exchange dynamics amongst IA Central Italian communities. The aim of such a reassessment is two-fold: firstly, to decentralise Central Italy in line with studies on other Mediterranean regions that have similarly dispelled distinctions between core and peripheral areas; secondly to shift attention away from evolutionary categories and other categories stemming from Roman ancient sources towards a perspective that stresses connectivity and patterns of human mobility or, in one phrase, connective mobility (Shaw 2001: 424) and exchange networks through the landscape. Ultimately, such a perspective positively encourages us to think without ethnic boundaries, the identification of which also originates from later ancient sources, yet has determined the archaeological definition of distinct cultural regions in IA Italy (Bradley, Isayev and Riva 2007).

\section{Towns, Systems and Networks across the Mediterranean}

'The unifying feature is not the accident of a nucleated pattern, whether or not this qualifies as urban; it is the intricate and often far-flung engagement with a wider, kaleidoscopic world.' (Horden and Purcell 2000: 122)

Connectivity, the core-concept behind the micro-ecological approach that Horden and Purcell developed in their seminal study (2000; see also Harris 2005a) and proposed for a novel way of understanding the long-term history of the Mediterranean, has been hailed as a 'watershed in the study of antiquity' (Shaw 2001: 453) by ancient historians, even marking a paradigm shift towards a connectedness model for the study of the Mediterranean as an analytical unit (Morris 2005; Malkin 2005). Despite criticism towards this study from an archaeological viewpoint (van Dommelen 2000), the concept of Mediterranean connectivity has vigorously entered the archaeological literature (Knapp and Blake 2005; Broodbank 2012), demonstrating the value of the connectedness concept in Mediterranean prehistory. Analyses of urbanization across the IA Mediterranean have not been immune from it either (Cunliffe and Osborne 2005); indeed, that such a concept began taking shape in the 1980s and sharpened along with the growing literature on globalisation, mobility and related issues in the social and historical sciences (Morris 2005: 31, 37-38) may partly explain why scholars set out to place Mediterranean towns within a theoretically-informed framework that stresses interaction and accessibility within town systems or networks across different cultural regions.

Undoubtedly, therefore, the connectedness concept and 'network thinking' has provided a fresh new impetus to the study of towns, at least for a comparative approach to IA urbanization in the Mediterranean; it has even encouraged comparative thinking of different communities across space, whether urban or not, within questions about the Eurocentric character of Greek ancient history, of which the Greek polis constitutes a key concept (Vlassopoulos 2007a). Yet, it is a paradox, though perhaps only deceptively so, that the concepts of Mediterranean connectivity and micro-ecology have in fact minimized, if not outright undermined, the significance of towns. Indeed, Horden and Purcell deem definitions of towns unsatisfactory because based on arbitrarily-estimated proportions of criteria such as size and population density (Horden and Purcell 2000: 92-96); they accordingly dismiss urban typologies and theories, because it is impossible to recognise 'the essence of 
Mediterranean urbanism' (Horden and Purcell 2000: 101). Ultimately, their intention is to eradicate the concept of town altogether and replace it with the features and characteristics of Mediterranean settlements identified '... less as separate and clearly definable entities and more as loci of contact or overlap between different ecologies' (Horden and Purcell 2000: 100). The most vociferous criticism of this perspective has come from ancient historians (Shaw 2001: 444-47; Harris 2005b: 29-34), which is perhaps unsurprising given that Horden and Purcell's focus on towns remains largely historical both in respect to the examples they use and the historiographical tradition they wish to challenge (Horden and Purcell 2000: 91). On the other hand, and this is where the paradox appears to be deceptive, this debate around towns has influenced the Mediterranean Iron Age insofar as the 'wider, kaleidoscopic world' referred to above is concerned. Other elements of the debate, namely the ecological interaction between centres of production and centres of consumption and other types of dynamic relationships between settlements have always been central themes of archaeological enquiry informed by survey evidence and Mediterranean landscape analysis, and have therefore not produced a visible effect on such an enquiry (cf. van Dommelen 2000: 233; Osborne 2005: 4). IA Central Italy is no exception to this; this is attested by the vast amount of survey archaeology and landscape studies that have allowed scholars to build a coherent account of human and cultural landscapes in the region over the last four decades. However, other, what we might call conceptual, issues of the debate are yet to have an impact on such an account: these issues entail the questioning and ultimate refutation of an urban core-non-urban-periphery perspective and, in view of that, the drive to decentralise the centre, the urban core.

Challenging this perspective is precisely the emphasis on Mediterranean connectivity and micro-ecologies as driving the system within which towns existed. This system is fluid not only ecologically but also conceptually: hence, not only is the distinction between types of settlement - urban, non-urban, rural - negligible, but the notion of central place itself becomes questionable at best (Horden and Purcell 2000: 102-105). The value of theories and methods for the identification of central places and of settlement hierarchies, many of which have driven archaeological enquiries on urban formation in IA Central Italy as we shall see, is firmly called in doubt because of their underlying 'systematic and mathematical approach' leading to a static picture of the fluid and dynamic nature of Mediterranean settlements (Horden and Purcell 2000: 104). In parallel to this and originating in postcolonial thought, network thinking does not exclude the existence of hierarchical relationships across space, but compellingly problematises these relationships and considers their dynamism (Constantakopoulou 2007; Malkin 2011), even within world-system historical perspectives (Vlassopoulos 2007a, 144-45, 168-70; 2007b; 2007c, 16-17); this is also the case with analyses of ancient imperial growth and expansion in which the emphasis is on the dynamic interaction between centres and frontier zones (Glatz 2009; cf. Constantakopoulou 2007: 6189). Recent studies on trade have similarly moved away from core-periphery relationships while focusing more productively on the multi-directional flows of goods and the social identities and power relations that drive and are themselves shaped by these flows (Foxhall 1998, Agbe-Davis and Bauer 2010). This appears to be a frontal assault on the entire framework within which past and present scholarship has investigated urban formation in IA Central Italy; yet, unlike the attacks of the historical 'consumer city' model and urban types, 
so resolutely resisted by ancient historians (Shaw 2001: 444-47), it has remained virtually undisputed since its inception.

Besides mere lack of scholarly communication, silence over this attack may indicate that such sharp positions are deemed as too extreme and irreconcilable with scholarship of the Italian Iron Age. Yet, these positions reflect a wider trend that is leading others to challenge core-periphery models in respect to the development of towns. The widening of this trend is most distinctively visible in archaeological and historical studies of the Archaic and later Greek world, which has long been practically coterminous with the polis and ancient urbanization and urbanism (Brock and Hodkinson 2000; Morgan 2003; Vlassopoulos 2007a; $2007 \mathrm{~b} ; 2007 \mathrm{c})$. Archaeological studies specifically devoted to the 'margins of the polis world' in the Greek early Iron Age and Archaic period (Morgan 2003: 2) ultimately focus upon political communities and their identities; in doing so, they have drawn attention to the variety of these latter and dismissed the ethnos-polis distinction as a product of the thinking of later Greek written sources and the modern historian's retrojection of this ancient thinking upon earlier material evidence (Morgan 2003). A similar attempt for IA Central Italy has not raised sufficient interest possibly because of its focus on later Roman periods (Bradley 2000).

Studies such as these have radically shifted the attention towards previously ignored themes and new questions in Greek archaeology; it seems to me that the picture we have built of IA Central Italy thus far would benefit considerably if we were to follow this trend seriously and take up issues which it has prompted. Doing so, it must be underlined, is only possible at the present time thanks to a growing body of material evidence particularly coming from those Italic regions deemed to be at the periphery of urbanization. Let us then turn now to Central Italy (Figure 1) and critically discuss the current state of the scholarship before moving on to examine and integrate well-known and new material evidence and the potential of this integration for transforming our perspective on towns.

\section{The Urban Core in the Mid-Tyrrhenian Region}

The current picture of the development of towns in Central Italy is, in fact, a relatively recent one: over the last two decades, new studies and settlement evidence from the mid-Tyrrhenian coastal region have settled a lasting debate over the relationship between indigenous settlements and Greek settlements that were newly established from the eighth century BC in the Italic peninsula and Sicily (Riva 2010a: 2-7). Until then, the relationship was largely seen as a hierarchical one, whereby the earlier urban formation of these new Greek communities was a catalyst for the urbanization of indigenous communities, mostly visibly so in Etruria. Rome was an exception in the independent processes leading to the synoikism of its earliest settlements and hence to its urbanization. While it may seem to be a gross generalization to some, it seems accurate to me to state that Etruscologists and Classical archaeologists fully endorsed this view; by contrast, pre- and proto-historians mostly rejected it on the basis of its underlying diffusionism that ultimately promoted Greek cultural superiority over indigenous communities. New evidence from both Etruria and Latium, and a growing dialogue between the two scholarly camps proved decisive for the prehistorians' arguments to gain wider acceptance and ultimately consensus (d'Agostino 2005). According to these arguments, indigenous urbanization in the mid-Tyrrhenian region was not only largely contemporary with the urbanization of non-indigenous communities, but those settlements that became 
urban in Tyrrhenian Etruria and Latium Vetus were already complex enough to be defined as proto-urban centres (Guidi 1998b; 2008). This complexity is primarily evaluated on the basis of two factors: firstly, the size of these proto-urban centres, which were much larger than previously and reflected densely populated settlement; secondly, the growth of burial grounds around these settlements, notably in Etruria, and the funerary material evidence that showed increasingly elaborate rituals (Riva 2010a: ch. 2). This view is largely accepted today, despite on-going questions around the modalities, timing and details of these momentous processes, and differences between these processes in, for example, Etruria and Latium (Guidi 2008: 176-179). This radical shift in outlook has coincided with changes in Greek archaeology and calls to abandon Hellenocentric views of the establishment of Greek communities across the Mediterranean (Hodos 2006; 2010).

\section{Proto-Urban, Urban and Central Places}

The changing perspective has had far-reaching consequences: firstly, it has promoted the building of a model of indigenous urbanization in Central Italy; secondly, in so doing it has reinforced the picture of a mid-Tyrrhenian urban core as opposed to a periphery at its geographical margins. The model describes two phases, namely the urbanization of a settlement following a proto-urban stage: encompassing the earliest proto-urban settlements, coastal south Etruria is seen, in this respect, to maintain pre-eminence over its neighbouring regions, including Rome and other centres south of the Tiber such as Gabii and Ardea, which followed suit (Guidi 2008: 176). The periphery, by contrast, includes areas, where the settlement pattern did not follow this model and remained non-urban, or it did so after a delay. While proto-historians largely subscribe to this picture (Pacciarelli 2000), recent studies of areas characterised by 'delayed urbanization' such as southern Latium, the Sabine region, Emilia Romagna and the north-eastern Italic regions have underlined the variety and complexity of processes and trajectories underlying urbanization across the Italic peninsula (Guidi and Santoro 2004; Guidi 2008). The emphasis on the Etruscan urban core of the model is furthermore concomitant with the role attributed to Etruria in the proto-urbanization of centres such as Capua and Pontecagnano in Campania, and Bologna and Verucchio in Emilia Romagna; such a role is deemed so vital as to conjecture the Etruscan colonization of these centres (Guidi 2008: 180; cf. Cuozzo 2007), and even to retroject such a political influence from Etruria over the margins to earlier periods, namely the final Bronze Age (Bietti Sestieri 1997). As recently noted, this Etrusco-centric scenario, which may be partly due to the dominance of Etruscology with its strong historiographic tradition in IA Italian archaeology (Vanzetti 2004: 19-21), has ironically revived a diffusionist perspective by replacing Greece with Etruria as the catalyst for change.

The concept of proto-urbanization itself, a key element of this model, requires close scrutiny. The term proto-urban was first used and applied to Central Tyrrhenian Italy by Renato Peroni (1969) in the 1960s in order to explain the socio-political changes that he identified in the settlements and cemeteries of the region in the Bronze and Iron Age transition (see also Gnesotto 2006). Apart from jts elusive definition (Vanzetti 2004: 26), the term generally refers to settlements that reached a certain size, which is regarded as indicative of a densely populated site, and that controlled a large territory within which a settlement hierarchy can be identified (Peroni and di Gennaro 1986; di Gennaro 2000). Such a

\begin{tabular}{|l|}
\hline Corinna Riva 1/4/13 14:08 \\
\hline Deleted: from \\
\hline Corinna Riva 1/4/13 14:10 \\
\hline Deleted: proto-urban \\
\hline
\end{tabular}


definition, however, depends on arbitrary calculations of the threshold beyond which a settlement is seen as large enough to be classified as proto-urban - which makes it effectively the central place so strongly criticized by Horden and Purcell. The problem becomes particularly acute when these thresholds also differentiate the Etruscan core from areas with 'delayed urbanization' (Guidi 2008: 184). The identification of a settlement hierarchy within a specific territory suffers from similar problems, as the hierarchy itself is defined by decreasing thresholds from the centre. The sizes of proto-urban centres' territories have moreover been determined by Thiessen Polygon analysis (di Gennaro 1982) and the Rank Size Rule (Guidi 1985; di Gennaro 2000) but these are mathematical analytical methods that are inherently at odds with the fluid settlement system of the Mediterranean as previously discussed. Even if scholars themselves have recognised a certain methodological naïveté in the early application of these methods, they have yet also duly noted their contribution to the shift in perspective away from Hellenocentric diffusionism that characterised research before the mid 1980s (Guidi 2000: 85). At the same time, the refinement of these methods and the introduction of others have recently helped to overcome some key problems related to Central Place theory, although the objections mentioned have by no means been resolved. Combining, for example, the XTENT model, which is based on Thiessen Polygons analysis, with a Digital Elevation Model (DEM) has allowed the reconstruction of hypothetical boundaries of distinct Etruscan territories while taking into consideration the limitations of the physical landscape more accurately (Redhouse and Stoddart 2011).

With these considerations in mind, it is worthwhile to reflect on the use of these methods and consider whether they are the best possible tools at our disposal for making inferences about distinct political territories. More fundamentally, we must also consider whether it is appropriate to presuppose political control at all in the early Iron Age as maintained by some (di Gennaro 1986). Recent work has tackled this issue by arguing for a dynamic formation of diverse political landscapes (Redhouse and Stoddart 2011). In fact, the greatest difficulty with this issue is to identify the nature of this control. It is certainly reasonable to expect that large communities such as those associated with proto-urban centres would have needed to exploit natural resources and that their subsistence strategies would have shifted to a much larger scale than those of other, smaller communities; however, assuming the centralization and political control of such exploitation on the basis of the archaeological evidence available is not axiomatic.

From the Early State to Political Authority in the Landscape

Ultimately, we must reflect on the conceptual genealogy of these assumptions: the model of a proto-urban centre controlling a specific territory derives from the Early State Module (ESM), which was initially proposed for Etruria (Renfrew 1975; Vanzetti 2004: 26), and from which applications for modeling inter-state socio-political interaction have been developed (Renfrew and Cherry 1986). The ESM itself originates from the Early State or Archaic State, which is an Anglo-American theoretical model that has dominated studies of the formation of early complex societies over the last few decades. Rooted in social and cultural evolutionism, the Early State was formulated as a form of sociopolitical organization that developed from the chiefdom level through a gradual evolutionary process in which various factors - economic, ideological, societal - interacted with one another (Claessen and 
Skalník 1978a; 1978b; Carneiro 1970; van de Velde 1985; Claessen and van de Velde 1985; more recently, Sanmartí 2004 and this volume). Several scholars have recently criticized this model for its failure to recognize the existence of multiple settlement hierarchies or indeed decentralization within a single state (Chapman 2008: 154-55; for the latest critical approach to Mediterranean state formation cf. Terrenato and Haggis 2011; see also Joffe 2002). While some have advocated, in its place, a 'fuzzy model' in which political control loses definite spatio-temporal boundaries (Stein 1998), others have been more extreme in their outright rejection of the Early State altogether (Smith 2003: especially 94-102). Smith's rejection is not only motivated by the theoretical basis in social evolution (Smith 2003: 33-36), which has been criticized more widely (Shennan 1993) but he is equally critical of the conceptualization of space as an 'absolute' or 'social constant' vis-à-vis the temporal transformations leading to social complexity. Smith calls this the 'absolutist ontology of space' (Smith 2003: 34), which he also firmly discards in favour of a relational notion of space and landscapes viewed '.. as social artifacts that are produced and reproduced through varying dimensions of spatial practice' (Smith 2003: 25; cf. Ashmore and Knapp 1999). According to this relational approach, and in contrast with the locational model of space that it refutes, landscapes are political not because they reflect political control or centralization, but rather because they are themselves 'constitutive elements of political life' and of political authority (Smith 2003: 7677). Hence, Smith's dismissal of the Early State is not just based on the refutation of evolutionary typologies of political forms and checklists of criteria for state formation (Smith 2003: 81, 96; Chapman 2008: 157). By conceiving space as being generated in conjunction with political relationships established through social and spatial practices, the concept of the state as 'an absolute phenomenon of political form' becomes awkward (Smith 2003: 77, 8085). Without ultimately denying the existence of states (Smith 2003: 108), Smith proposes the constitution of political relationships and of political authority through landscape as an alternative approach to the investigation of political landscapes. This approach takes into account three interconnected areas of analysis: spatial experience, namely material practices through space, spatial perception and the codes and signs underlying it, and finally spatial imagination and representation. All these three areas encapsulate different processes by which inequality and subordination are constructed, from the power over resources and labour to the political control in the production of meaning (Smith 2003: 72-74).

From a theoretical viewpoint, this different approach may at first appear to find some convergence with the Marxist outlook of the school of Italian pre- and proto-history (Guidi 1998a: 678) although the inherent materialism of the latter is incompatible with it. More importantly, this approach poses vast methodological problems for IA Central Italy not least because of the lack of data that can lend themselves to such a detailed analysis, particularly as far as spatial perception and imagination are concerned. The origins and constitution of political authority in the early Iron Age and later have thus far been a fruitful area of research in Tyrrhenian Etruria (Iaia 1999; De Santis 2005; Riva 2010a). This research, however, is mainly restricted to cemetery data, which do not allow studying how political authority operates within the larger public apparatus of governance in the landscape (Smith 2003: 108109). Attempts to connect these data to the wider context have done so by looking at the extension and nature of the settlements and its cemeteries rather than the wider landscape (Pacciarelli 2000). This is unfortunately inevitable, as we rely chiefly on survey evidence 
and, with few exceptions, lack detailed investigation (Guidi 2008: 177). Analogous, albeit less severe, problems concern the study of the political landscape of later periods, namely the early Archaic period; again save important exceptions that reveal political landscapes were structured through ritual and funerary practices, the increasing density of rural occupation in the sixth century BC is principally known from survey evidence (Rendeli 1993; Zifferero 2002; 2005; Carafa 2004). The disparate state of the data in different Italian regions is an additional problem.

Yet, a critical look at the conceptual foundation of the Early State encourages us to reevaluate the available evidence and to tackle two final key issues. The first one is the relationship between urbanization and state formation; the second one concerns the relationship between the evolutionary outlook of this model and the settlement categories that are derived from Roman textual sources but applied to IA Italy.

Some studies deem proto-urbanization as a constituent of incipient state formation, and urbanization itself as an important component of statehood (Guidi 1998b; 2000; 2008: 187; di Gennaro 2000); others underline the distinction between urbanization and state formation (Bradley 2000: 32; Riva 2010a: 21-22). Conversely, conceiving of landscapes as constitutive of political authority through social and spatial practices help us to clarify the reflexive relationship between spatial forms (nucleated/dispersed, urban/non-urban settlement) and temporal (political) transformations through practice (Smith 2003: 25, 71-72); in this way, we can trace the structuration of political power in the landscape through time. Highlighting the heterogeneity of the re-occupation of the landscape around proto-urban centres in the course of the eighth century in south Etruria (Iaia and Mandolesi 1995; 2010) allows us, for example, to reconstruct a scenario of 'constitutive political landscapes', in which different social groups strategically occupied sites for resource exploitation and communication and for contact within very fluid spatial and social relationships. Indeed, this heterogeneous scenario places emphasis on the formation of a connective tissue around the proto-urban and later urban centres that functioned more as a settlement network than as a settlement hierarchy system, driven more by exchange flows through material practices than by political dependence upon a central place within state boundaries. Alternatively, a study on Umbria, traditionally considered as the non-urban periphery of Etruria (see below), has argued for the need to understand non-urban or 'territorial' states over a long time period (900-300 BC) through the analysis of archaeological, epigraphic and textual sources, emphasizing the dynamic and diverse nature of Italic states and state formation as an on-going process (Bradley 2000: 29-41). The Umbrian states are seen effectively as akin to the ethnos states of the Greek world (Bradley 2000: 58).

The second issue in this critical overview is that evolutionary thinking, which underlies the Early State and the proto-urban concept, is ethnocentric, because the urban state is seen as a more developed form of state than the 'tribal state' in the non-urban margins (Rowlands 1989; Shennan 1993; cf. d'Ercole 2000). Such modern ethnocentrism is, in fact, amplified by the use of ancient settlement categories and deeply value-laden terms for the Iron Age such as pagi and vici (Dench 1995: 128, 130-40; cf. Bradley 2000: 56-59; Zifferero 2002: 250; see now Stek 2009). As their nature and relationship is unclear even for later historical periods, their relevance for the Iron Age is questionable at best (Dench 1995: 135). While I would not deny key regional differences across Central Italy, it seems to me that we are now in a 
position to go beyond such evolutionary views and problematic terms; we can now move towards a new analytical framework that stresses exchange flows and dynamics instead of static landscapes, state and ethnic boundaries, and that makes the centre and margins look less different than they are usually made to appear. Within this framework, the focus is upon mobility through exchange flows and social and spatial practices that over a relatively long time period gave rise to political relationships, which themselves were never stable and led to alternative or indeed opposing forms of political authority, domination and subordination.

\section{Exchange Networks Beyond Urban Centres}

Within this analytical framework, I would like to consider the thriving and abatement of settlements as integrated aspects of the same network both within the so-called urban core and its margins, which I will discuss by examining selected sites (Figure 1). Some settlements in Etruria represent such dynamism, like Marsiliana d'Albegna, Murlo (Poggio Civitate), Acquarossa and Bisenzio, which flourished in the seventh century but did not survive beyond the sixth century; outside Etruria, I will consider sites in Umbria and the Apennines in order to illustrate a similar dynamism of local exchange networks.

$<<$ insert figure 1 around here $>>>>$

Our knowledge of Marsiliana has been largely limited to its cemeteries although newlyexcavated residential contexts are changing the picture considerably (Camilli et. al. 2005; Casi 2007; Camilli et al. 2008); the settlement at Bisenzio is known from surface survey only and from its excavated burial grounds (Delpino 1977). Conversely, the excavated settlements of Murlo and Acquarossa illustrate the wealth and the forms of power that this engendered in smaller, albeit different, settlements: Acquarossa was a relatively populous centre of around 25 ha at the height of its growth (Roos and Wikander 1986), while Murlo has been characterized as a ceremonial, political or civic centre (Torelli 2000; Rathje 2007). It was an architectural complex that comprised an Orientalizing elite residential building, a large workshop and a tripartite structure with possibly a religious function; all of these were destroyed by fire and were replaced by a later Archaic and much more elaborate structure with a closed square plan (Nielsen and Tuck 2001). At both sites, the construction of monumental architectural complexes not only reveals the remarkable access to wealth and resources of these centres, but also the political authority of those who controlled them; of these complexes, the Archaic building at Murlo and the later buildings A and C of Area F at Acquarossa were decorated with figured terracottas whose iconographic programmes displayed the public and political character of the buildings (Strandberg Olofsson 1986; Sassatelli 2000; Rathje 2007). Other buildings with similar public or semi-public functions must have existed at large urban centres in Etruria as attested, for example, by the remains of elite buildings at Veii/Piazza d'Armi (Bartoloni 2003: 58) and further afield, in Rome (the Regia), Satricum (Wikander and Wikander 1990: 202-205), and possibly at smaller settlements similar to Murlo elsewhere such as Otricoli in the middle Tiber valley (Colonna 2001: 16).

Although different hypotheses have been put forward to explain the demise of these settlements, they all have something in common: they stress the crystallization of Etruscan city-states' control over their territory following deep social transformations in the sixth century, and the pressure that this exerted upon these politically autonomous communities, 
which were ultimately incorporated into the political orbit of the city-states. Thus, the demise of Bisenzio was a result of Orvieto (Volsinii)'s territorial expansion that was followed by the foundation of a frontier sanctuary on Bolsena Lake (Berlingò 2005: 563-64). Similarly, Murlo and Acquarossa were incorporated within the territories of Chiusi, and Tarquinia or Orvieto respectively (Torelli 2000: 68; Sassatelli 2000: 153). The isolated character of these sites and the 'princely' nature of their political authority are often underlined and contrasted with the power of the large urban centres that absorbed them (Torelli 2000: 72; Sassatelli 2000: 147). This is by no means an unlikely scenario; but the contrast between urban and non-urban forms of political power appears less sharp once we examine the wider context and consider instability not simply as a trait of princely authority but as intrinsic to the exchange networks within which all these settlements developed and/or declined.

Marsiliana and the Albegna valley are in this respect particularly instructive: the destruction of the elite community of Marsiliana by Vulci once the area came under the city's control (Acconcia 2005; Cardosa 2005) is a catastrophist scenario that is hardly justified by the archaeological evidence. Indeed, recent studies of the well-explored archaeological landscape of the Albegna valley have highlighted the development of urban and rural settlements in the valley side by side since the seventh century, suggesting that changes in landscape occupation between the seventh and sixth centuries BC were due to mobility and demographic increase in the area and related to shifting exchange and trade networks (Perkins 1999; 2010). This is not only seen in the changing distribution and nature of burial clusters around Marsiliana, Magliano and Saturnia that probably related to small rural settlements in the valley (Perkins 1999: 80-100) but it is also indicated by the establishment of a new large redistribution or market centre at Doganella towards the end of the seventh century, and by the distribution of transport amphorae produced there (Perkins and Walker 1990; Perkins 1999: 180-81). The centralization of amphora production and the distribution of amphorae and other ceramic forms related to the transport and storage of agricultural produce such as dolia illustrate the exchange links between Doganella and other settlements in the lower valley that underlay the growth of political relationships between them (Perkins 1999: 181-88). The evidence from Podere Tartuchino, a farm established at the end of the sixth century, confirms the existence of a network, in which surplus production at single farms connected these to each other and to Doganella (Attolini and Perkins 1992). The involvement of Marsiliana in the network is confirmed by new evidence like a late Archaic rural residence with a quadrangular plan and open courtyard, which is comparable to the Casa dell'Impluvium at Roselle and the earliest surburban villa at the Auditorium in Rome (Camilli et al. 2008). Archaic coastal emporia at Fonteblanda and Talamonaccio that serve the valley further testify to a network that extended beyond the local economy (Ciampoltrini and Firmati 2002; Perkins 2005: 115). Although acknowledged by some (Acconcia 2005; Cardosa 2005), the power and direct involvement of Vulci over these developments, including the foundation of Doganella, lacks any concrete evidence other than the close proximity between Vulci and Doganella and the problematic correlation between material culture and political influence (Perkins 2010).

The case of Marsiliana demonstrates that we may need to readjust catastrophist hypotheses and notions of ruptures as invoked for the demise of Murlo and Acquarossa (Sassatelli 2000: 153), while recognizing continuous change as a feature to which all 
networks were subjected (Purcell 2005: 267). With more excavations of non-urban sites, we are in a better position to understand the complex and changing nature of these networks beyond the alleged impact of political influence from the city-states, and the relationship between stable and controlling large urban centres and unstable, controlled non-urban settlements (Perkins 1999: 191).

$<<$ insert figure 2 around here $>>>>$

A boundary area where oscillations in the extension of political control of specific Etruscan city-states conceal the complexity and changing nature of political relationships across the landscape is Monti della Tolfa (Figure 2). Rich in mineral resource and a topographical watershed between Tarquinia's and Cerveteri (Caere)'s territories, the area has been systematically explored through survey and excavation of a few settlements (Zifferero 1995; 2000). After the abandonment of Final Bronze Age sites, the re-occupation of this area in the eighth century with the emergence of sites in strategic and defensive positions points to the control and exploitation of its mineral and woodland resources by competing social groups (Iaia and Mandolesi 2010). This goes hand in hand with the growth of Castellina del Marangone down the coast: a medium-size settlement on a plateau overlooking the mouth of the Marangone river and equidistant from Tarquinia and Cerveteri, Castellina developed from the eighth century as a metal processing site thanks to its prosperous maritime contacts (Gran Aymerich 2005; Prayon 2005). Despite suggestions that Castellina came under Cerveteri's political control (Prayon 2005), its continued occupation to the third century BC, the distribution of smaller settlements from the coast to the hinterland towards Mount Tolfaccia overlooking the same valleys and river basins, as well as the emergence of three Archaic sanctuaries in the area of Castellina and further south at Punta della Vipera, all indicate an autonomous network or, as has been suggested, a 'buffer zone' between the territories of Tarquinia and Cerveteri (Rendeli 1993: 240-45). The dynamic process of elite groups' occupation and exploitation of the Monti della Tolfa becomes noticeable in the seventh century with the emergence of isolated tumulus burials and smaller settlements such as Monterano and Pian della Conserva in the Mignone valley, that may be interpreted as another exchange network among autonomous communities (Rendeli 1993: 299-303); to this network belongs San Giovenale, a flourishing settlement located on a plateau by a small tributary of the Mignone river (Roos and Wikander 1986). Only towards the end of the seventh and in the sixth centuries do the increasing number of new medium-size settlements, open sites and the expansion of existing ones point to a capillary occupation of the Mignone valley and exploitation of its natural resources; the open sites linked to burial grounds, in particular, indicate the stable occupation of land given to agricultural use and management (Zifferero 2000: 239-47). These changes have been attributed to the political control of Cerveteri (Rendeli 1993: 329-30) and the close similarity of funerary architecture and other types of material culture in the area to those from Cerveteri have been considered as further evidence of this control (Rendeli 1993: 343). Correlating specific styles of material culture with political control, however, is highly problematic because of the underlying assumption that style is a passive reflection of political or even ethnic identities. Style is, on the contrary, a product of social and cultural practice (Shanks and Tilley 1987: 146-71; Conkey 1990: 1214) and can be actively manipulated in order to negotiate or maintain boundaries. Evidence of cult sites in the area from the sixth century, scarce as it is so far, offers more reliable support 
for the hypothesis of consolidated political control of the city-state through a structured ritual landscape (Rendeli 1993: 363; Zifferero 1995: 340-48; 2002). Ultimately, however, we are unable to distinguish whether the city-state maintained spatial boundaries or whether these were the result of political relationships established within the settlement network of the area. Such a distinction may even be insignificant, as the stylistic and material affinities with Cerveteri may be evidence of political relationships that autonomous communities established with the city-state by drawing social boundaries through stylistic distinction (sensu Bourdieu); in time, such relationships may in turn have ensured the control of Cerveteri's interests in the area.

\section{Exchange Networks Beyond Etruria}

The picture outlined by this kind of evidence is not only one of fluctuating political control across the landscape and the political relationships that were established alongside it, but also one in which exchange flows and networks were responsible for this fluctuation. Nowhere is the role of these networks more visible than at some key settlements and areas outside the urban core of Tyrrhenian Etruria across inland Central Italy (Figure 3). At the same time, one should not underestimate the concurrent changing networks further afield, westwards and across the Tyrrhenian Sea, visible in the establishment of coastal trading settlements from Etruria to southern France (Riva 2010b). Once deemed periphery because largely unknown by field research, inland and Apennine central Italy has recently come to scholarly attention, and revealed a picture of highly articulated exchange networks linking the Tyrrhenian and Adriatic shores of the peninsula.

$<<<$ insert figure 3 around here $>>>>$

The Tiber valley, in particular, has been at the centre of recent research interest (Patterson 2004; Patterson and Coarelli 2008). Studies of the middle Tiber valley as a frontier area, for example, have noted the growth of secondary sites at the northern margins of the territory of Etruscan Veii from the end of the eighth century along routes of communication and exchange across inland central Italy, and the social and regional mobility along these routes (Cifani 2005: 154, 158): this evidence not only points to the permeability of state boundaries and the autonomy of such frontier areas, but also to the nature of these areas as a locus for exchange (Cifani 2001: 114). Indeed, the archaeological evidence from the eighth to the sixth centuries on both sides of the middle Tiber valley attests to this, from Otricoli and Amelia (cf. Sisani 2008: 63-64) to Todi (Stopponi 2008). Acquarossa itself, placed in the Vezza river valley that linked the Tiber with the territory of Tarquinia, shows cultural relations with Falerii, Cerveteri, Vulci and Tarquinia (Colonna 1973); its sixth-century demise must be seen in conjunction with the demise of nearby Monte Piombone, the growth of Bomarzo at the Vezza confluence with the Tiber, and of Orvieto further north, but also with concomitant changes on the eastern side of the Tiber. Here, in the course of the sixth century, the site of Todi, located at the south-west-looking curve of the Tiber before this latter narrows down into the Forello gorge, grew to become a 25 ha site (Cifani 2001: 118); its cemeteries of Logge and San Raffaele contained elite burials of sixth to fifth century date with prestige objects and imports from Orvieto (Bruschetti 2001: 142-44, 147; Stopponi 2008: 22). 
From the late sixth century, the Tiber became a distinctive point of convergence rather than a boundary area as settlements east of the valley between Orvieto and Perugia - some argue, even further north to modern Città di Castello (Sisani 2008) - came under Etruscan control (Stopponi 2008). Given that this hypothesis is based on often later epigraphic evidence, ancient sources, Etruscan imports and 'Etruscanised' material culture, it is challenging, however, to detect the dynamics of such processes in the Archaic period beyond recognizing a heightened human mobility. Other scholars have discussed these changes more cautiously in terms of Etruscan trade links (Bradley 2000: 97-98); indeed, reading the archaeological and epigraphic evidence in this way, and emphasizing the diversity of local community identities (Bradley 2000: 92-100), allow us to recognize the role of the changing networks that link different communities on both sides of the valley to the decline of certain settlements and conversely the flourishing and urbanization of others. Hence, the marginal location of sixth-century Acquarossa was not in respect to Orvieto, but to a new network, of which a central node was Orvieto, towards the east bank of the Tiber and Todi; through Todi, Volsinian and other Etruscan goods and imports reached Umbrian sites, including Colfiorito (Bonomi Ponzi 1997: 87-88, 136; Bruschetti 2001: 147). Acquarossa's demise, in other words, was not the direct result of Orvieto's political control, but of a changing network at the centre of which was this burgeoning Etruscan town; this network involved Todi, one of the earliest settlements in Umbria to become urban in the fifth century along with Gubbio, another key site located on trans-Apennine routes to the Adriatic (Stopponi 2008: 22). At Todi, the monumentalization of its urban sanctuaries with architectural terracottas modelled on those from the slightly earlier Belvedere temple at Orvieto (Bruschetti 2001: 151-52; Stopponi 2008: 22) indicates strong political relationships between the two centres, resulting from the elites' social and material practices mostly discernible in the earlier and contemporary funerary evidence. Further support in favour of this picture are the concurrent changes at Terni and its basin in the Nera valley, which was a crucial node of exchange between Tyrrhenian and Adriatic Central Italy from the Final Bronze Age (Ponzi Bonomi 2001); scholars interpret Terni as an important early IA proto-urban centre, not unlike those of south Etruria (Cifani 2001: 112-13). Such momentous developments, which are also visible in Terni's cemeteries (Acciaierie, S. Pietro in Campo) (Leonelli 2003; Broncoli 2006) and the circulation of its material culture in Etruria (Colonna 2001: 18), must be seen in conjunction with the growth of Otricoli as a river port further south on the east bank of the river from the end of the eighth century (Colonna 1999: 28-29). Terni's central role in this scenario, however, changed after the middle of the sixth century when Orvieto became the central node of the exchange network (Ponzi Bonomi 2001: 330).

A significant feature underlying these developments and interaction as a whole in Umbria is the topography of the region, which is characterized by high mountains and isolated plains and valleys that together create a relative lack of large fertile plains (Bradley 2000: 48-53): this has not only influenced the location of sizeable settlements along river valley terraces and valley bottoms, but also the specific selection of mountainous areas for occupation (Cifani 2001: 123). The material culture of some upland settlements nevertheless reveals extraordinarily wide-ranging connections that challenge these occupation patterns, and confirms the suggestions that social, rather than physical factors affect the movement of people and material in mountainous regions (Horden and Purcell 2000: 132). This is 
particularly the case of those settlements located along the communication routes between the Valle Umbra and the Apenninic range to the east and the Adriatic side, such as Colfiorito, and that are linked by the Chienti and Potenza river valleys (Bonomi Ponzi 1997). While, as it is expected, the location at key intersections determined the flourishing of such sites, only now are we able to gauge the extension and fluctuation of specific exchange networks that affected settlement growth and decline thanks to new research in these areas. One particular district that has been subject to intensive fieldwork in the last ten years or so is the upper Esino valley, which is situated in a $45 \mathrm{~km}$-long and fairly wide valley between two branches of the Apennines: this is the so-called 'Camertine trough' extending from Camerino in the south-east to Arcevia in the north-west. Here, the site of Matelica, set at a particularly strategic point of communication between two mountain passes, Fossato di Vico leading to Gubbio to the north and Colfiorito to the south, has been thoroughly investigated since the mid-1990s: a series of large cemeteries and related settlements dated from roughly the eighth to the sixth centuries have been excavated along the Esino river terraces (Silvestrini and Sabbatini 2008). Although some burials were in use since the ninth century, the extraordinary display of wealth and prestige objects in seventh-century elite burials and the upsurge of habitation areas demonstrate the level of prosperity that these communities reached in this period (Sabbatini 2008a; Biocco and Silvestrini 2008). The occupation of the surrounding valley with evidence of early deforestation furthermore testifies to the agricultural exploitation of the valley that was essential for the survival of these sizeable communities (Biocco and Silvestrini 2008: 27, 37). A comparable scenario consisting of a much more sparse IA occupation away from the river terraces may be gauged from preliminary results of the survey of an area just north of Matelica, in the environs of Fabriano (Pearce et al. 2009) where older excavations in the modern city had also located wealthy Orientalizing elite burials (Sabbatini 2008b).

The grave-goods and imports of these and of the contemporary elite burials at Matelica reveal extraordinarily far-reaching connections across inland and Tyrrhenian central Italy on the one hand, and with the Adriatic and Apulian regions on the other (Silvestrini and Sabbatini 2008), and therefore a prosperous exchange network, in which the upper Esino valley played a significant role. Another noteworthy indicator of its role in the network comes from the settlement of Trebbio located on the east bank of the upper Tiber valley between Sansepolcro and Città di Castello (Iaia and Moroni Lanfredini 2009). Trebbio developed between the eighth and the sixth centuries BC and reached 20 ha in size at its peak between the late seventh and the early sixth centuries (Iaia 2009, 54); its growth stemmed from its location on vital trade routes as attested by its diverse material culture, as well as the intense large-scale ceramic production taking place there (Gennusa et al. 2007; Iaia and Moroni Lanfredini 2009). Although the excavation of the site is still ongoing, the preliminary results show an interesting pattern: the contexts from the seventh century are closely related to the material from inland Marche and, above all, Matelica although links with Colfiorito further south are not absent; later, between the end of the seventh and the first half of the sixth century, the contexts at Trebbio show relations with the Umbro-Romagnolo cultural region, conceivably the result of the economic demise of Verucchio to the north-west on the Adriatic (Iaia 2009: 51-54). Unexpectedly, the material record at Trebbio shows no links with Etruria or Cortona that is considered to have extended its control to this area (Iaia 2009: 51). 
The fading of Trebbio's links with Matelica are consistent with the general collapse of the latter in the course of the sixth century, which is indicated by the rapid contraction of its cemeteries (Sabbatini 2008a: 57). Importantly, this decline corresponded in turn to the growing wealth in the cemeteries of Colfiorito south of Matelica, which entered the exchange network of Todi and Orvieto as described above, but was also in contact with the newly burgeoning emporic centres on the Adriatic coast such as Numana (Bonomi Ponzi 1997: 88).

Evidence on the funerary ritual and spatial arrangement of the cemeteries of these intraApennine settlements give us an important indication of the social and material practices of specific social groups in these communities that gave rise to political relationships with nearby and more distant communities. But what may primarily show the establishment of such political relationships across different communities in the landscape are the sanctuaries that were established mostly on high grounds across inland Central Italy from the sixth century BC (Bradley 2000: 62-77 for an overview) and the series of hillforts in upland areas (Bradely 2000, 53-62). Though difficult to date in some cases, the hillforts did not only function as a system of control and defence of the landscape; several were, in fact, associated with burial grounds and were permanent settlements (Bradley 2000, 55). The sanctuaries generally lacked built structures but were often located on visible and strategic sites in the landscape and were related to the hillforts as was the case, for instance, at Monte Torre Maggiore (Bonomi Ponzi 2006). They have produced votive deposits with a variety of bronze statuettes and some epigraphic evidence that demonstrate their use by local communities (Bradley 2000: 67). Given the modern plundering of many of these sites, however, we must also concede that specific evidence of the use of these spaces by outsiders or individuals showing off outside relationships may be missing: the famous Mars from Monte Santo near Todi, which was produced in Orvieto and inscribed with a dedication in Umbrian, may in fact exemplify such missing evidence, even if Todi is primarily seen as a cosmopolitan frontier settlement (cf. Bradley 2000: 71)

\section{Conclusions}

Through selected case-studies from Etruria to the Apennines, I have examined the complexity of exchange networks beyond the large Etruscan urban centres and their links to other networks across inland Central Italy from the early IA to the fifth century BC. I have suggested that the instability of such networks is mostly visible in the success - urban or otherwise - and demise of some settlements and that it should be seen as a phenomenon that was integral to the fluctuations of political relationships and control across the landscape. It is, however, extremely difficult to identify the social and spatial practices that gave rise to such political relationships in the material record of the landscape, although our evidence for Tyrrhenian Etruria is particularly abundant and more amenable to answer these questions. Ultimately, only a detailed study of the archaeological, iconographic and epigraphic records of the landscape of a particular area may enable us to understand these practices and the processes that led to specific forms of political authority and power relations over a relatively long time period. For inland and Apennine central Italy, the record is very limited, partly because of its marginalization in scholarly research, and partly because of the genuine difficulties of data retrieval in upland landscapes (Pearce et al. 2009). This picture is, however, changing fast thanks to increasing interest and new fieldwork in these regions and it 
is a first result that we are now able to study the connective mobility that linked urban and non-urban settlements across central Italy.

The Iron Age was a momentous period in the history and archaeology of Central Italy: urbanization and urbanism are undoubtedly key aspects of such a period. Amidst the changes and instability that I have described above, most of the large urban centres in the midTyrrhenian region did not decline but indeed thrived: there were, as always, winners and losers. Yet, only an approach that takes networks and the complexity of exchange amongst urban and non-urban settlements seriously enables us to see towns as an explanandum, not an explanans' (Abrams 1978: 30) of the much wider context in which they prospered and declined.

\title{
Acknowledgments
}

I would like to thank Bernard Knapp and Peter van Dommelen for inviting me to participate in this project. I have benefitted very much from personal discussions with Cristiano Iaia and Elena Isayev, and from seminar discussions that took place at Cambridge and Newcastle. Finally, both Cristiano Iaia, Alessandro Mandolesi and Simon Stoddart have kindly let me read their unpublished forthcoming articles: I thank them all.

\begin{abstract}
About the author
Corinna Riva is Senior Lecturer in Mediterranean Archaeology at University College London. Her research interests cover the Iron Age of Italy and the Central Mediterranean. Since 2002, she has been co-director of the Upper Esino Valley Survey (Marche, Italy). She is the author of The Urbanization of Etruria (Cambridge University Press, 2010).
\end{abstract}




\section{References}

Abrams, $\mathrm{P}$.

1978 Towns and economic growth: some theories and problems. In P. Abrams and E.A. Wrigley (eds.), Towns in Societies. Essays in Economic History and Historical Sociology, 9-33. Cambridge: Cambridge University Press.

Acconcia, V.

2005 Aspetti archeologici e produttivi della bassa e media valle dell'Albegna. In A. M. Sgubini Moretti (ed.), Dinamiche di sviluppo delle città nell'Etruria meridionale. Veio, Caere, Tarquinia, Vulci. Atti del $23^{\circ}$ Convegno di studi etruschi ed italici, Roma, Veio, Caere/Pyrgi, Tarquinia, Tuscania, Vulci, Viterbo, 1-6 ottobre 2001, 603-11. Pisa: Istituti Editoriali e Poligrafici Internazionali.

Attolini, I., and P. Perkins

1992 The excavation of an Etruscan farm at Podere Tartuchino. Papers of the British School at Rome 60: 1-76.

Bartoloni, G.

2003 Veio-Piazza d'Armi: un'abitazione a capanna. In I. Van Kampen (ed.), Dalla capanna alla casa. I primi abitanti di Veio. Catalogo della mostra, 57-59. Formello: Comune di Formello and Museo dell'agro veientano.

Bauer, A. A. and A. S. Agbe-Davies

2010 Rethinking trade as a social activity: an introduction. In A. A. Bauer and A. S. AgbeDavies (eds.), Social Archaeologies of Trade and Exchange. Exploring Relationships Among People, Places, and Things, 13-28. Walnut Creek, California: Left Coast Press.

Berlingò, I.

2005 Vulci, Bisenzio e il lago di Bolsena. In A. M. Sgubini Moretti (ed.), Dinamiche di sviluppo delle città nell'Etruria meridionale. Veio, Caere, Tarquinia, Vulci. Atti del $23^{\circ}$ Convegno di studi etruschi ed italici, Roma, Veio, Caere/Pyrgi, Tarquinia, Tuscania, Vulci, Viterbo, 1-6 ottobre 2001, 559-66. Pisa: Istituti Editoriali e Poligrafici Internazionali.

Bietti Sestieri, A.M.

1997 Italy in Europe in the Early Iron Age. Proceedings of the Prehistoric Society 63: 371-402.

Biocco, E., and M. Silvestrini

2008 Popolamento e dinamiche insediative. In M. Silvestrini and T. Sabbatini (eds.),

Potere e splendore. Gli antichi piceni a Matelica. 19 aprile-31 ottobre 2008, 27-39.

Rome: L''Erma' di Bretschneider.

Bonomi Ponzi, L.

1997 La necropoli plestina di Colfiorito di Foligno. Perugia: Quattroemme.

2006 Il santuario di Monte Torre Maggiore. In C. Angelelli and L. Bonomi Ponzi (eds.), Terni-Interamna Nahars. Nascita e sviluppo di una città alla luce delle più recenti ricerche archeologiche, 109-28. Rome: École Française de Rome.

Bradley, G. 
2000 Ancient Umbria. State, Culture, and Identity in Central Italy from the Iron Age to the Augustan Era. Oxford: Oxford University Press.

Brock, R., and Hodkinson (eds.)

2000 Alternatives to Athens. Varieties of Political Prganisations and Community in Ancient Greece. Oxford: Oxford University Press.

Broncoli, M.

2006 Ultimi scavi nella necropoli di S. Pietro in Campo-ex poligrafico Alterocca di Terni: la tomba 98/1. In C. Angelelli and L. Bonomi Ponzi (eds.), Terni - Interamna Nahars. Nascita e sviluppo di una città alla luce delle più recenti ricerche archeologiche, 33-55. Rome: École Française de Rome.

Broodbank, C.

2012 The Making of the Middle Sea. An Archaeological History of the Mediterranean from its Earliest Peopling until the Iron Age. London: Thames and Hudson.

Bruschetti, P.

2001 Cultura etrusca e mondo italico: l'esempio di Todi. In G.M. Della Fina (ed.), Gli Umbri del Tevere. Atti dell' $8^{\circ}$ Convegno Internazionale di Studi sulla Storia e l'Archeologia dell'Etruria. Annali della Fondazione per il Museo 'Claudio Faina', 141-61. Rome: Edizioni Quasar.

Carafa, $P$.

2004 Il paesaggio etrusco-italico in H. Patterson (ed.), Bridging the Tiber. Approaches to Regional Archaeology in the Middle Tiber Valley, 45-59. London: British School at Rome.

Camilli A., L. Arcangeli, C. Casi, C. Grilli, E. Pellegrini, and F. Rossi

2005 Manciano (GR). Lavori lungo la statale 'Maremmana'. Notiziario della Soprintendenza per i Beni Archeologici della Toscana 1: 323-25.

Camilli A., S. Bimbi, F. Borghini, G. Giorgi, A. Pecci, G. Pieragnoli, E. Rossi, Ca. Sanchirico, E. Santoro, G. Tofani, and A. Zifferero

2008 Manciano (GR). Marsiliana d'Albegna: nuovi dati dall'abitato e dal suburbio. Notiziario della Soprintendenza per i Beni Archeologici della Toscana 4: 285-309.

Cardosa, M.

2005 Paesaggi nel territorio di Vulci dalla tarda protostoria alla romanizzazione,. In A.M. Sgubini Moretti (ed.), Dinamiche di sviluppo delle città nell'Etruria meridionale: Veio, Caere, Tarquinia Vulci. Atti del $23^{\circ}$ Convegno di studi etruschi ed italici, Roma, Veio, Caere/Pyrgi, Tarquinia, Tuscania, Vulci, Viterbo, 1-6 ottobre 2001, 551-57. Pisa: Istituti Editoriali e Poligrafici Internazionali.

Carneiro, R. L.

1970 A theory of the origin of the state. Science. New Series 169: 733-38.

Casi, C.

2007 Scoperta l'antica Caletra? Archeo 10: 10-11.

Chapman, R.

2008 Alternative States. In J. Habu, C. Fawcett and J.M. Matsunaga (eds.), Evaluating Multiple Narratives. Beyond Nationalist, Colonialist, Imperialist Archaeologies, 144-65. New York: Springer.

Ciampoltrini, G., and M. Firmati 
2002 The Blacksmith of Fonteblanda. Artisan and trading activity in the northern

Tyrrhenian in the sixth century BC. Etruscan Studies 9: 29-36.

Cifani, G.

2001 Il popolamento umbro nella media valle del Tevere. In G. M. Della Fina (ed.), Gli Umbri del Tevere. Atti dell' $8^{\circ}$ Convegno Internazionale di Studi sulla Storia e l'Archeologia dell'Etruria. Annali della Fondazione per il Museo 'Claudio Faina', 109-39. Rome: Edizioni Quasar.

2002 Notes on the rural landscape of central Tyrrhenian Italy in the 6th-5th c. B.C. and its social significance. Journal of Roman Archaeology 15: 247-60.

2005 I confini settentrionali del territorio veiente. In A. M. Sgubini Moretti (ed.), Dinamiche di sviluppo delle città nell'Etruria meridionale. Veio, Caere, Tarquinia, Vulci. Atti del $23^{\circ}$ Convegno di studi etruschi ed italici, Roma, Veio, Caere/Pyrgi, Tarquinia, Tuscania, Vulci, Viterbo, 1- ottobre 2001, 151-61. Pisa: Istituti Editoriali e Poligrafici Internazionali.

Claessen, H. J. M. and P. Skalník

1978a The Early State: Theories and Hypotheses. In H. J. M. Claessen and P. Skalník (eds.), The Early State, 3-29. The Hague, Paris, New York: Mount Publishers.

Claessen, H. J. M. and P. Skalník

1978b The Early State: Models and Reality. In H. J. M. Claessen and P. Skalník (eds.), The Early State, 637-50. The Hague, Paris, New York: Mount Publishers.

Claessen, H. J. M. and P. van de Velde,

1985 Sociopolitical evolution as complex interaction. In H. J. M. Claessen, P. van de Velde and M. Smith (eds.), Development and Decline. The Evolution of Colonna, G. Sociopolitical Organization, 246-63. Massachussetts: Bergin and Garvey Publishers.

1973 Ricerche sull'Etruria interna volsiniese. Studi Etruschi 41: 45-72.

1999 L'iscrizione del biconico di Uppsala: un documento del paleoumbro. In Incontro di Studi in Memoria di Massimo Pallottino, 19-29. Pisa-Rome: Istituti Editoriali e Poligrafici Internazionali.

2001 Gli Umbri del Tevere. In G. Della Fina (ed.), Gli Umbri del Tevere. Atti dell'VIII Convegno Internazionale di Studi sulla Storia e l'Archeologia dell'Etruria. Annali della Fondazione per il Museo 'Claudio Faina', 9-31. Rome: Edizioni Quasar.

Conkey, M.

1990 Experimenting with style in archaeology: some historical and theoretical issues. In M. Conkey and C. Hastorf (eds.), The Uses of Style in Archaeology, 5-17.

Cambridge: Cambridge University Press.

Constantakopoulou C.

2007 The Dance of the Islands. Insularity, Networks, the Athenian Empire and the Aegean World. Oxford: Oxford University Press.

Cunliffe, B., and Osborne R. (eds.)

2005 Mediterranean Urbanization 800-600 BC. Proceedings of the British Academy 126. Oxford: Oxford University Press.

Cuozzo, M. 
2007 Ancient Campania. Cultural interaction, political borders and geographical boundaries. In G. Bradley, E. Isayev and C. Riva (eds.), Ancient Italy. Regions without Boundaries, 224-67. Exeter: Exeter University Press.

d'Agostino, B.

2005 La città. In A. M. Sgubini Moretti (ed.), Dinamiche di sviluppo delle città nell'Etruria meridionale: Veio, Caere, Tarquinia Vulci. Atti del $23^{\circ}$ Convegno di studi etruschi ed italici, Roma, Veio, Caere/Pyrgi, Tarquinia, Tuscania, Vulci, Viterbo, 1-6 ottobre 2001, 21-26. Pisa: Istituti Editoriali e Poligrafici Internazionali.

D'Ercole, V.

2000 Paesaggi di potere dell'Abruzzo protostorico. In G. Camassa, A. De Guio, F. Veronese (eds.), Paesaggi di potere: problemi e prospettive. Atti del seminario Udine, 16-17 maggio 1996, 121- 52. Rome: Quasar.

Delpino, F

1977 La prima età del ferro a Bisenzio. Aspetti della cultura villanoviana nell'Etruria meridionale interna. Memorie dell'Accademia Nazionale dei Lincei Classe di Scienze morali, storiche e filologiche 8.21: 453-93.

Dench, E.

1995 From Barbarians to New Men. Greek, Roman, and Modern Perceptions of Peoples from the Central Apennines. Oxford: Clarendon Press.

De Santis, A.

2005 Da capi guerrieri a principi : la strutturazione del potere politico nell'Etruria protourbana. In A.M. Sgubini Moretti (ed.), Dinamiche di sviluppo delle città nell'Etruria meridionale: Veio, Caere, Tarquinia Vulci. Atti del $23^{\circ}$ Convegno di studi etruschi ed italici, Roma, Veio, Caere/Pyrgi, Tarquinia, Tuscania, Vulci, Viterbo, 1-6 ottobre 2001, 615-31. Pisa: Istituti Editoriali e Poligrafici Internazionali.

di Gennaro, F.

1982 Organizazzione del territorio nell'Etruria meridionale protostorica: applicazione di un modello grafico. Dialoghi di Archeologia 2: 102-12.

1986 Forme di insediamento tra Tevere e Fiora dal Bronzo Finale al principio dell'età del ferro. Olschki: Firenze.

2000 'Paesaggi di potere': l'Etruria meridionale in età protostorica. In G. Camassa, A. De Guio, F. Veronese (eds.), Paesaggi di potere: problemi e prospettive. Atti del seminario Udine, 16-17 maggio 1996, 95-119. Rome: Quasar.

Foxhall, L.

2005 Village to city: staples and luxuries? Exchange networks and urbanization. In R.

Osborne and B. Cunliffe (eds.), Mediterranean Urbanization 800-600 BC.

Proceedings of the British Academy 126: 233-248. Oxford: Oxford University Press. Gennusa R., C. Iaia, A. Moroni Lanfredini, and M. Pacciarelli

2007 Sansepolcro (AR). Trebbio. Notiziario della Soprintendenza per i Beni Archeologici della Toscana 2: 545-49.

Glatz, C.

2009 Empire as network: spheres of material interaction in Late Bronze Age Anatolia. Journal of Anthropological Archaeology, 28: 127-41. 
Gran-Aymerich, J.

2005 La Castellina près de Civitavecchia. La vocation d'un site aux confins de Caeré et de Tarquinia. In A. M. Sgubini Moretti (ed.), Dinamiche di sviluppo delle città nell'Etruria meridionale. Veio, Caere, Tarquinia, Vulci. Atti del 23o Convegno di studi etruschi ed italici, Roma, Veio, Caere/Pyrgi, Tarquinia, Tuscania, Vulci, Viterbo, 1-6 ottobre 2001, 657-64. Pisa: Istituti Editoriali e Poligrafici Internazionali.

Guidi, A.

1985 An application of the rank size rule to protohistoric settlements in the middle Tyrrhenian area. In C. A. T. Malone and S. K. F. Stoddart (eds.), Papers in Italian Archaeology IV. Vol. 3. Patterns in Protohistory, 217-42. Oxford: British Archaeological Reports.

1998a Clarke in Mediterranean archaeology. Antiquity 72: 678-80.

1998b The emergence of the state in central and in Italy. Acta Archaeologica 69: 139-61.

2000 Il Lazio e la Sabina tra la tarda età del Bronzo e l'età del ferro. In G. Camassa, A. De Guio, F. Veronese (eds.), Paesaggi di potere: problemi e prospettive. Atti del seminario Udine, 16-17 maggio 1996, 85-94. Rome: Quasar.

2008 Archeologia dell' Early State: il caso di studio italiano. Ocnus 16: 175-92.

Guidi A., and P. Santoro

2004 Centri della Sabina tiberina in epoca pre-romana. In H. Patterson (ed.), Bridging the Tiber. Approaches to Regional Archaeology in the Middle Tiber Valley, 179-86. London: British School at Rome.

Harris, W.V. (ed.)

2005a Rethinking the Mediterranean. Oxford: Oxford University Press.

2005b The Mediterranean and ancient history. In W.V. Harris (ed.), Rethinking the Mediterranean, 1-42. Oxford: Oxford University Press.

Hodos, T.

2006 Local Responses to Colonization in the Iron Age Mediterranean. London: Routledge.

2010 Globalization and Colonization: a view from Iron Age Sicily. Journal of Mediterranean Archaeology 23.1: 81-106.

Horden, P., and N. Purcell

2000 The Corrupting Sea. A Study of Mediterranean History. Oxford: Blackwell.

2005 Four years of corruption: responses to critics. In W. V. Harris (ed.), Rethinking the Mediterranean, 348-75. Oxford: Oxford University Press.

Iaia, C.

1999 Simbolismo funerario e ideoleogia alle origini di una civiltà urbana. Forme rituali nelle sepolture 'villanoviane' a Tarquinia e Vulci e nel loro entroterra. Firenze: All'Insegna del Giglio. 
2009 I reperti fittili e metallici: cronologia e rapporti culturali. In C. Iaia and A. Moroni Lanfredini (eds.), L'età del Ferro a Sansepolcro. Attività produttive e ambiente nel sito di Trebbio, 33-54. Perugia: Aboca Edizioni.

Iaia, C., and A. Mandolesi

1995 Topografia dell'insediamento dell'VIII secolo in Etruria meridionale. Journal of Ancient Topography 31993 (1995): 7-48.

2010 Comunità e territori nel Villanoviano evoluto dell'Etruria meridionale. In Proceedings of the 9th Colloquium Preistoria e Protostoria in Etruria (ValentanoPitigliano settembre 12-14 settembre 2008), 61-78. Milano: Edizioni Centro Studi Preistoria e Archeologia.

Iaia, C., and A. Moroni Lanfredini (eds.)

2009 L'età del Ferro a Sansepolcro. Attività produttive e ambiente nel sito di Trebbio. Perugia: Aboca Edizioni.

Joffe, A.

2002 The rise of secondary states in the Iron Age Levant. Journal of the Economic and Social History of the Orient 45.4: 425-67.

Knapp, A. B. and W. Ashmore

1999 Archaeological Landscapes: Constructed, Conceptualized, Ideational. In W. Ashmore and A. B. Knapp (eds.), Archaeologies of Landscape: Contemporary Perspectives, 1-30. Oxford: Blackwell.

Knapp, A. B. and E. Blake

2005 Prehistory of the Mediterranean: The Connecting and Corrupting Sea. In A. B. Knapp and E. Blake (eds.), The Archaeology of Mediterranean Prehistory, 1-23. Oxford: Blackwell.

Leonelli, $\mathrm{V}$.

2003 La necropoli della prima età del ferro delle acciaierie a Terni. Contributi per un'edizione critica. Firenze: All'Insegna del Giglio.

Malkin, I. (ed.)

2005 Mediterranean Paradigms and Classical Antiquity. London and New York: Routledge.

2011 A Small Greek world. Networks in the Ancient Mediterranean. Oxford: Oxford University Press.

Morgan, C.

2003 Early Greek States Beyond the Polis. London: Routledge.

Morris, I.

2005 Mediterraneanization. In I. Malkin (ed.), Mediterranean Paradigms and Classical Antiquity, 30-55. London and New York: Routledge.

Nielsen, E., and A. Tuck

2001 An Orientalizing period complex at Poggio Civitate (Murlo): a preliminary view. Etruscan Studies 8: 35-63.

Osborne, R.

2005 Urban Sprawl: What is Urbanization and Why does it Matter? In R. Osborne and B. Cunliffe (eds.), Mediterranean Urbanization 800-600 BC. Proceedings of the British Academy 126: 1-16. Oxford: Oxford University Press. 
Pacciarelli, M.

2000 Dal villaggio alla città. La svolta protourbana del 1000 a.C. nell'Italia tirrenica.

2nd edition. Firenze: All'Insegna del Giglio.

Patterson, H. (ed.)

2004 Bridging the Tiber. Approaches to Regional Archaeology in the Middle Tiber Valley. London: British School at Rome.

Patterson, H., and F. Coarelli (eds.)

2008 Mercator Placidissimus. The Tiber Valley in Antiquity. New Research in the Upper and Middle River Valley. Rome, 27-28 February 2004. Rome: Quasar.

Pearce J., M. Pretzler, and C. Riva

2009 The upper Esino valley survey, Marche, Italy (2002-2006): a preliminary discussion of aims, methods and results, in M. Silvestrini and T. Sabbatini (eds.), Fabriano e l'area appenninica dell'alta valle dell'Esino dall'età del bronzo alla romanizzazione. Atti del Convegno Fabriano 19-20-21 maggio 2006, 81-102. Ancona: SACI Edizioni.

Perkins, P.

1999 Etruscan Settlement, Society and Material Culture in Central Coastal Etruria. (BAR International Series 788). Oxford: J. and E. Hedges.

2005 Who lived in the Etruscan Albegna Valley? In P. Attema, A. Nijboer and A. Zifferero (eds.), Communities and Settlements from the Neolithic to the Early Medieval Period. Proceedings of the Sixth Conference of Italian Archaeology, University of Groningen, Groningen Institute of Archaeology, The Netherlands, April 15-17, 2003, 109-17. BAR International Series 1452. Oxford: Archaeopress.

2010 The cultural and political landscape of the Ager Caletranus, North-West of Vulci. In P. Fontaine (ed.), L'Etrurie et l'Ombrie avant Rome. Cité et territoire, Etudes de Philologie, d'Archéologie et d'Histoire Anciennes, 103-22. Bruxelles: Institut Historique Belge de Rome.

Perkins, P., and S. Walker

1990 Field survey of the Etruscan city at Doganella. Papers of the British School at Rome 58: $1-144$.

Peroni, R.

1969 Per uno studio dell'economia di scambio in Italia nel quadro dell'ambiente culturale dei secoli intorno al mille a.C. in Parola del Passato XXIV: 134-160.

Peroni, R., and F. di Gennaro

1986 Aspetti regionali dello sviluppo dell'insediamento protostorico nell'Italia centromeridionale alla luce dei dati archeologici e ambientali. Dialoghi di Archeologia 4.2 (3rd series): 193-200.

Ponzi Bonomi, L.

2001 Tra Appennini e Tevere : il ruolo dei Naharci nella formazione della cultura umbra. In G.M. Della Fina (ed.), Gli Umbri del Tevere. Atti dell' $8^{\circ}$ Convegno Internazionale di Studi sulla Storia e l'Archeologia dell'Etruria. Annali della Fondazione per il Museo 'Claudio Faina', 319-41. Rome: Quasar.

Prayon, F.

Formatted: Justified, Indent: Left: $0 \mathrm{~cm}$, First line: $0 \mathrm{~cm}$, Line spacing: single, Tabs:Not at $1.5 \mathrm{~cm}$

\section{Corinna Riva 1/4/13 14:28}

Formatted: Font:Times New Roman

Corinna Riva 1/4/13 14:28

Formatted: Font:Times New Roman

Corinna Riva 1/4/13 14:28

Formatted: Font:Times New Roman 
2005 Lo sviluppo urbanistico del sito etrusca di Castellina del Marangone (Comune di S. Marinella, Prov. Roma). In A. M. Sgubini Moretti (ed.), Dinamiche di sviluppo delle città nell'Etruria meridionale. Veio, Caere, Tarquinia, Vulci. Atti del $23^{\circ}$ Convegno di studi etruschi ed italici, Roma, Veio, Caere/Pyrgi, Tarquinia, Tuscania, Vulci, Viterbo, 1-6 ottobre 2001, 665-75. Pisa: Istituti Editoriali e Poligrafici Internazionali.

Purcell, N.

2005 Statics and Dynamics: Ancient Mediterranean Urbanism. In R. Osborne and B. Cunliffe (eds.), Mediterranean Urbanization 800-600 BC. Proceedings of the British Academy 126: 249-72. Oxford: Oxford University Press.

Rathje, A.

2007 Murlo, Images and Archaeology. Etruscan Studies 10: 175-84.

Redhouse, D.I., and S.K.F. Stoddart

2011 Mapping Etruscan state formation. In N. Terrenato and D. Haggis (eds.), State Formation in Italy and Greece. Questioning the Neoevolutionist Paradigm, 162-78. Oxford: Oxbow.

Rendeli, M.

1993 Città aperte. Ambiente e paesaggio rurale organizzato nell'Etruria meridionale costiera durante l'età orientalizzante e arcaica. Rome: Gruppo Editoriale Internazionale.

Renfrew, A. C.

1975 Trade as action at a distance: questions of interaction and communication. In J. A. Sabloff and C. C. Lamberg-Karlovsky (eds.), Ancient Civilisations and Trade, 3-59. Albuquerque: School of American Research and University of New Mexico.

Renfrew, A. C., and J. Cherry (eds.)

1986 Peer-Polity Interaction and Socio-Political Change. Cambridge: Cambridge University Press.

Riva, C.

2010a The Urbanization of Etruria. Funerary Practices and Social Change, 700-600 BC. New York: Cambridge University Press.

2010b Trading Settlements and the Materiality of Wine Consumption in the North Tyrrhenian Sea Region. In B. Knapp and P. van Dommelen (eds.), Material Connections: Mobility, Materiality and Mediterranean Identities, 210-32. London and New York: Routledge.

Roos, P., and Ö. Wikander. (eds.)

1986 Architettura Etrusca nel Viterbese. Ricerche Svedesi a San Giovenale e Acquarossa, 1956-1986. Rome: De Luca.

Rowlands, M.

1989 A question of complexity. In D. Miller, M. Rowlands and C. Tilley (eds.), Domination and Resistance, 29-40. London: Unwin Hyman.

Sabbatini, T.

2008a La società attraverso l'organizzazione delle necropoli. In M. Silvestrini and T. Sabbatini (eds.), Potere e splendore. Gli antichi piceni a Matelica. 19 aprile-31 ottobre 2008, 51-57. Rome: L' 'Erma' di Bretschneider. 
2008b L'orientalizzante a Fabriano. In M. Silvestrini and T. Sabbatini (eds.), Potere e splendore. Gli antichi piceni a Matelica. 19 aprile-31 ottobre 2008, 123-38. Rome: L'Erma' di Bretschneider.

Sanmartí, J.

2004 From local groups to early states: the development of complexity in protohistoric Catalonia. Pyrenae. Revista de Prehistòria i Antiguitat de la Mediterrània Occidental 35.1: 7-41.

Sassatelli, G.

2000 Il palazzo. In A. Dore, M. Marchesi, and L. Minarini. (eds.), Principi etruschi tra Mediterraneo ed Europa, 145-53. Bologna: Museo Civico Archeologico.

Sgubini Moretti, A. M. (ed.)

2005 Dinamiche di sviluppo delle citta' nell'Etruria meridionale. Veio, Caere, Tarquinia, Vulci. Atti del $23^{\circ}$ Convegno di studi etruschi ed italici, Roma, Veio, Caere/Pyrgi, Tarquinia, Tuscania, Vulci, Viterbo, 1-6 ottobre 2001. Pisa: Istituti Editoriali e Poligrafici Internazionali.

Shanks, M., and C. Tilley

1987 Re-Constructing Archaeology. Theory and Practice. New Studies in Archaeology. Cambridge: Cambridge University Press.

Shaw, B.

2001 Challenging Braudel: a new vision of the Mediterranean. Journal of Roman Archaeology 14: 419-53.

Shennan, S.

1993 After social evolution: a new archaeological agenda? In N. Yoffee and A. Sherratt (eds.), Archaeological Theory: Who Sets the Agenda?, 53-59. Cambridge: Cambridge University Press.

Silvestrini, M., and T. Sabbatini (eds.)

2008 Potere e splendore. Gli antichi Piceni a Matelica. 19 aprile-31 ottobre 2008. Rome: L'"Erma' di Bretschneider.

Sisani, S.

2008 Dirimens Tiberis? I confini tra Etruria ed Umbria. In H. Patterson and F. Coarelli (eds.), Mercator Placidissimus. The Tiber Valley in Antiquity. New Research in the Upper and Middle River Valley. Rome, 27-28 February 2004, 45-85. Rome: Quasar.

Smith, A. T.

2003 The Political Landscape. Constellations of Authority in Early Complex Polities. Berkeley: University of California Press.

Stein, G. J.

1998 Heterogeneity, power and political economy: some current research issues in the archaeology of Old World complex societies. Journal of Archaeological Research 6: 1-44.

Stek, T.

2009 Cult Places and Cultural Change in Republican Italy. A Contextual Approach to Religious Aspects of Rural Society after the Roman Conquest. Amsterdam: Amsterdam University Press.

Stopponi, S. 
2008 La media valle del Tevere fra Etruschi ed Umbri. In H. Patterson and F. Coarelli (eds.), Mercator Placidissimus. The Tiber Valley in Antiquity. New Research in the Upper and Middle River Valley. Rome, 27-28 February 2004, 15-44. Rome: Quasar. Strandberg Olofsson, M.

1986 L'area monumentale di Acquarossa. In P. Roos and Ö. Wikander (eds.), Architettura etrusca nel Viterbese. Ricerche svedesi a San Giovenale e Acquarossa, 1956-1986, 81-9. Rome: De Luca.

Terrenato, N., and D. Haggis (eds.)

2011 State Formation in Italy and Greece. Questioning the Neoevolutionist Paradigm. Oxford: Oxbow.

Torelli, M.

2000 Le regiae etrusche e laziali tra orientalizzante e arcaismo, in A. Dore, M. Marchesi and L. Minarini. (eds.), Principi etruschi tra Mediterraneo ed Europa, 67-78. Bologna, Museo Civico Archeologico.

van Dommelen, P.

2000 Writing ancient Mediterranean landscapes. Journal of Mediterranean Archaeology 13: $230-36$.

Vanzetti, A.

2004 Risultati e problem di alcune attuali prospettive di studio della centralizzazione e urbanizzazione di fase protostorica in Italia. In P. Attema (ed.), Centralization, Early Urbanization and Colonization in First Millennium BC Italy and Greece. Part I: Italy, 1-28. Leuven: Peeters.

van de Velde, P.

1985 Early state formation in Iron Age Central Europe. In H. J. M. Claessen, P. van de Veldeand M. Smith (eds.), Development and Decline. The Evolution of SocioPolitical Organization, 170-182. Massachussetts: Bergin and Garvey Publishers. Vlassopoulos, K.

2007a Unthinking the Greek Polis. Ancient Greek History Beyond

Eurocentrism. Cambridge: Cambridge University Press.

2007b Between East and West: the Greek poleis as part of a World-System. Ancient West and East 6: 91-111.

2007c Beyond and below the polis: networks, associations, and the writing of Greek History. Mediterranean Historical Review 22:1: 11-22.

Wikander, C., and Ö. Wikander

1990 The early monumental complex at Acquarossa. A preliminary report. Opuscola Romana 18: 189-205.

Zifferero, A.

1995 Economia, divinità e frontier: sul ruolo di alcuni santuari di confine in Etruria meridionale. Ostraka 4.2: 333-50.

2000 Architettura costruita e paesaggio rurale in Etruria meridionale: un contributo dal territorio cerite. In A. Zifferero (ed.), L'architettura funeraria a Populonia tra IXe VI secolo a.C. Atti del Convegno. Castello di Populonia, 30-31 ottobre 1997, 193250. Rome: CNR and Università degli Studi di Siena. 
2002 The geography of the ritual landscape in complex societies. In P. Attema, G.-J. Burgers, E. Van Joolen, M. van Leusen and B. Mater (eds.), New Developments in Italian Landscape Archaeology. Theory and Methodology of Field Survey. Land Evaluation and Landscape Perception. Pottery Production and Distribution.

Proceedings of a Three-Day Conference Held at the University of Groningen April 13-15, 2000, 246-65. Oxford: Archeopress.

2005 La formazione del tessuto rurale nell'agro cerite: una proposta di lettura, in A.M. Sgubini Moretti (ed.), Dinamiche di sviluppo delle città nell'Etruria meridionale: Veio, Caere, Tarquinia Vulci. Atti del $23^{\circ}$ Convegno di studi etruschi ed italici, Roma, Veio, Caere/Pyrgi, Tarquinia, Tuscania, Vulci, Viterbo, 1-6 ottobre 2001, 257-72. Pisa: Istituti Editoriali e Poligrafici Internazionali. 